\title{
Crew and passenger deaths from vessel accidents in United Kingdom passenger ships since 1900
}

\author{
Tim Carter ${ }^{1}$, John G. Williams ${ }^{2}$, Stephen E. Roberts ${ }^{2}$ \\ ${ }^{1}$ Norwegian Centre for Maritime and Diving Medicine, Haukeland University Hospital, Norway \\ ${ }^{2}$ Medical School, Swansea University, Swansea, United Kingdom
}

\begin{abstract}
Background: There is very limited systematic analysis of the causes and consequences of maritime accidents across the whole passenger sector during the twentieth century either in United Kingdom (UK) or in other maritime nations, but some of the larger events have been the subject of detailed investigations that led to improved safety measures. In recent years, there has been increased attention to the analysis of passenger ship accidents, especially in relation to the two now dominant markets: vehicle/passenger ferries and cruise ships. Materials and methods: Long-term trends since 1900 in passenger and crew deaths on UK seagoing passenger ships that have sustained a maritime accident, as defined by Lloyds Register, have been collated and analysed.

Results: Over the course of the $20^{\text {th }}$ century, there has been a continuous fall in the number of incidents and in their severity. This may be a reflection of improved vessel safety, however the scale and nature of UK passenger shipping has also changed markedly over the period.

Conclusions: In addition to the reducing frequency of deaths it is apparent that the majority of fatalities in both crew and passengers came from a very small number of major events during the study period. Although there has been no major disaster involving a UK passenger ship in the last 30 years, major casualties with heavy loss of life continue in the world passenger fleet, in recent years involving flags such as Greece, Indonesia, Italy, Panama and The Philippines.
\end{abstract}

(Int Marit Health 2019; 70, 1: 1-10)

Key words: passenger ships, deaths, United Kingdom, maritime casualties, fire, collision, foundering, grounding

\section{INTRODUCTION}

Major incidents involving United Kingdom (UK) passenger ships and resulting in deaths of crew members and passengers are now rare. When they occur, as with the Herald of Free Enterprise in 1987, they are a cause of great public concern. The loss of R.M.S. Titanic in 1912 was a major international news story at the time and remains a source of fascination to this day. This investigation will look in more depth at UK passenger ship incidents resulting in deaths since 1900 . Fortunately, there have been none since 2000 , but this is in part a consequence of the modest decline in the number of passenger ships registered in the UK as well as improvements in ship design and aids to navigation.
Case notes on all UK passenger ships involved in incidents that led to deaths among crew and/or passengers have been collated. These indicate that, in peacetime, the main causes of such incidents are foundering (including capsize and disappearance), wrecking and stranding, collisions and fires or explosions. The toll of casualties from these causes is examined and time trends evaluated.

The war years 1915-1918 and 1939-1945 are excluded from this analysis because of the very different pattern of ship loss during these periods. However, at least one major incident after 1945 has been attributed to uncleared mines and one to terrorist action.

Four study periods have been used: 1910-1914, 1919-1939, 1946-1969, 1970-1999. The first two have 
been selected to cover peacetime before the first war and then the inter-war years. The break at 1970 enables the last years when ships dominated passenger transport to be separated from the more recent period when relatively few people used sea transport as a necessity, beyond short sea ferry routes, and the majority of passengers were aboard cruise ships.

This study analyses a long run of data collected in a systematic way about a single country's fleet. Thus it bridges the gap between reports on individual incidents, popular texts about passenger ship disasters and a number of more rigorous investigations of risks to life aboard passenger ships that have been published in this century. Insights from these sources will be reviewed in the discussion section of this article. The authors have published two previous studies on other maritime sectors and time periods that use similar search strategies and analyses [1, 2].

\section{MATERIALS AND METHODS}

A database of major passenger ship incidents resulting in fatalities was created as a sub-file of a wide collection of information on such incidents in all maritime sectors. The records relate to vessels designated as seagoing passenger ships registered in the UK. Coastal passenger ships and commercial river craft are excluded. The sources of information used were firstly reports from marine accident investigations, conducted by the Marine Accident Investigation Branch since 1989 and in previous years variously by the Board of Trade, the Ministry of Transport, the Department of Trade and Industry etc. [3]. Other information sources used were annual Lloyd's Register quarterly and annual casualty reports and data [4, 5], Lloyd's Maritime Information Services casualty information [6]. Extensive searches of the British Newspapers Archive [7], Welsh Newspapers Online [8], the wrecksite.eu website [9], and the Ships Nostalgia website [10], death enquiry and death registration files held at the Registry of Shipping and Seamen and various other searches.

A total of 90 incidents were identified in the study period. The following information was obtained from the information sources; the date of the incident, the ship name, ship type, its gross tonnage and age. The following information was sought on the fatal incident: crew and passenger numbers lost, nature and circumstances of incident, location, routing, type of cargo, weather conditions, numbers of passengers and crew saved. Not all of this information was available for every incident.

\section{RESULTS}

Figure 1 shows total fatalities (passengers and crew) by year. It can be seen that the pattern is erratic as some years are dominated by a single major incident, while for others

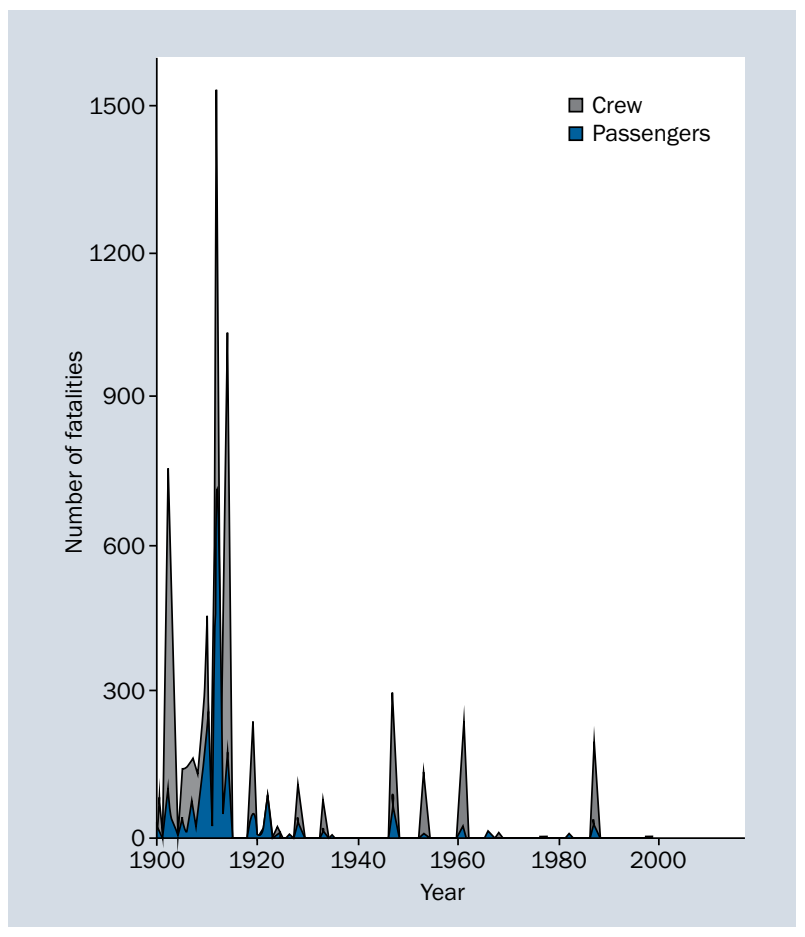

Figure 1. Trends in fatalities among crew and passengers that arose from ship accidents in United Kingdom passenger shipping since 1900

there were no reported events. Predictably large numbers of both passenger and crew deaths occur in years when a major incident(s) has occurred. A long run reduction in incidents and fatalities can be seen. The reasons for this will be discussed later after an analysis of the causes of incidents and their consequences.

Table 1 summarises information on incidents by time period and primary cause, as reported. A major decline in the frequency of events can be seen between the 1900-1914 period and 1919-1939. Fires and explosions featured in a greater proportion of events in the periods after 1919, while collisions, wrecks/strandings and founderings all became rare after 1946. This may be a consequence of improvements in navigational aids with the widespread use of radar and location beacons.

Adverse weather conditions were recorded in 34 of the incidents that did not involve fires or explosions, although weather conditions could not be established from the information sources in a few cases. Fog was particularly linked to collisions and close to shore wrecks and strandings. Storms or gales were commonly linked to founderings.

Fires and explosions resulted in 174 crew deaths, and at least 408 passenger fatalities. Since 1946 few of these incidents have led to passenger fatalities as they arose mainly in engine rooms and other crew spaces and were contained without impairing the seaworthiness of the ship (Table 2). 
Table 1. Reported major incidents involving United Kingdom seagoing passenger ships that resulted in loss of life

\begin{tabular}{llllllll}
\hline & Years & All incidents & Fire/explosion & Foundering/lost & Collision & Wreck/stranding & Other \\
\hline All years & 90 & $90(1$ p.a. & $24(26 \%)$ & $17(18 \%)$ & $17(18 \%)$ & $26(28 \%)$ & $6(6 \%)$ \\
$1900-1914$ & 15 & $51(3.6$ p.a. $)$ & $8(15 \%)$ & $11(21 \%)$ & $9(17 \%)$ & $20(39 \%)$ & $3(6 \%)$ \\
$1919-1939$ & 21 & $26(1.5$ p.a. $)$ & $9(34 \%)$ & $3(11 \%)$ & $7(27 \%)$ & $5(19 \%)$ & $2(7 \%)$ \\
$1946-1969$ & 24 & $9(0.4$ p.a.) & $6(66 \%)$ & 1 & 0 & 1 & 1 \\
$1970-1999$ & 30 & $4(0.1$ p.a. $)$ & 1 & 2 & 1 & 0 & 0
\end{tabular}

One incident in the period 1946-1969 was attributed to uncleared or drifting mines that were a legacy from the Second World War, while for one terrorist action was suspected. 'Other' includes severe storm damage; p.a. - per annum

Table 2. Deaths resulting from major incidents involving United Kingdom seagoing passenger vessels

\begin{tabular}{|c|c|c|c|c|c|c|c|}
\hline & \multicolumn{2}{|c|}{$\begin{array}{l}\text { All deaths: numbers, percentage } \\
\text { of total in crew, ratios }\end{array}$} & \multirow{2}{*}{$\begin{array}{l}\text { Fire/explo- } \\
\text { sion number } \\
\text { of deaths }\end{array}$} & \multirow{2}{*}{$\begin{array}{l}\text { Foundering/ } \\
\text { /lost number } \\
\text { of deaths }\end{array}$} & \multirow{2}{*}{$\begin{array}{l}\begin{array}{l}\text { Collision } \\
\text { number } \\
\text { of deaths }\end{array} \\
980(36 \%)\end{array}$} & \multirow{2}{*}{$\begin{array}{l}\text { Wreck/ } \\
\text { /stranding num- } \\
\text { ber of deaths } \\
242(35 \%)\end{array}$} & \multirow{2}{*}{$\begin{array}{l}\begin{array}{l}\text { Other } \\
\text { causes }\end{array} \\
11\end{array}$} \\
\hline All years & Crew & $2125(33 \%)$ & & & & & \\
\hline & Passengers & $4208+$ & $408+$ & $1675+$ & 1686 & $436+$ & 3 \\
\hline & Total & $6333+$ & $582+$ & $2393+$ & 2666 & $678+$ & \\
\hline & Deaths per incident & $70+$ & $24+$ & $140+$ & 156 & $26+$ & \\
\hline & Deaths per year & $70+$ & $6+$ & $27+$ & 30 & $8+$ & \\
\hline \multirow{5}{*}{$\begin{array}{l}1900-1914 \\
(15)\end{array}$} & Crew & $1700(34 \%)$ & 64 (24\%) & 557 (32\%) & $876(34 \%)$ & 197 (21\%) & 6 \\
\hline & Passengers & $3290+$ & $195+$ & $1187+$ & 1658 & $250+$ & 0 \\
\hline & Total & $4990+$ & $259+$ & $1744+$ & 2534 & $447+$ & \\
\hline & Deaths per incident & $97+$ & $32+$ & $158+$ & 282 & $22+$ & \\
\hline & Deaths per year & $332+$ & $17+$ & $116+$ & 168 & $30+$ & \\
\hline \multirow{5}{*}{$\begin{array}{l}\text { 1919-1939 } \\
(21)\end{array}$} & Crew & $221(38 \%)$ & $26(64 \%)$ & $58(31 \%)$ & $100(79 \%)$ & $32(14 \%)$ & 5 \\
\hline & Passengers & 356 & 16 & 128 & 26 & 186 & 0 \\
\hline & Total & 577 & 42 & 186 & 126 & 218 & 5 \\
\hline & Deaths per incident & 22 & 5 & 62 & 18 & 44 & \\
\hline & Deaths per year & 26 & 2 & 9 & 6 & 10 & \\
\hline \multirow{5}{*}{$\begin{array}{l}1946-1969 \\
(24)\end{array}$} & Crew & $145(25 \%)$ & $68(24 \%)$ & $64(23 \%)$ & 0 & $13(100 \%)$ & 0 \\
\hline & Passengers & 421 & 213 & 205 & 0 & 0 & 3 \\
\hline & Total & 566 & 281 & 269 & 0 & 13 & 3 \\
\hline & Deaths per incident & 62 & 46 & 269 & 0 & 13 & \\
\hline & Deaths per year & 23 & 12 & 11 & 0 & 0.5 & \\
\hline \multirow{5}{*}{$\begin{array}{l}1970-1999 \\
(30)\end{array}$} & Crew & $43(22 \%)$ & 0 & 39 (20\%) & 4 & 0 & 0 \\
\hline & Passengers & 157 & 0 & 155 & 2 & & \\
\hline & Total & 200 & 0 & 194 & 6 & & \\
\hline & Deaths per incident & 25 & & 77 & & & \\
\hline & Deaths per year & 7 & & 6 & & & \\
\hline
\end{tabular}

Foundering and collisions caused the largest number of fatalities. A few events with large numbers of fatalities in the years 1900-1914 dominated this category, notably the Titanic in 1912 and The Empress of Ireland in 1914 accounted for 2526 deaths, almost $40 \%$ of all fatalities in the whole study period. More recently The Herald of Free Enterprise disaster accounted for 193 of the 200 deaths between 1970 and 1999.

The number of survivors after an incident varies greatly, but is not always reliably recorded. Table 3 presents the 
Table 3. Details of ship accidents that led to 6 or more crew or passenger fatalities in United Kingdom passenger ships: ordered chronologically

\begin{tabular}{|c|c|c|c|c|c|}
\hline Year & $\begin{array}{l}\text { Name } \\
\text { of ship }\end{array}$ & Type of ship & $\begin{array}{l}\text { Gross } \\
\text { tonnage, } \\
\text { age of ship }\end{array}$ & $\begin{array}{l}\text { Seafarers (and } \\
\text { passengers) } \\
\text { lost }\end{array}$ & Details of the maritime casualty \\
\hline 1987 & $\begin{array}{l}\text { Herald } \\
\text { of Free } \\
\text { Enterprise }\end{array}$ & $\begin{array}{l}\text { MV Passenger } \\
\text { ferry }\end{array}$ & 7951,6 & $38(155)$ & $\begin{array}{l}\text { Capsized soon after departing Zeebrugge, Belgium for Dover } \\
\text { with the bow doors left open. } 41 \text { crew and } 326 \text { passengers } \\
\text { rescued. }\end{array}$ \\
\hline 1982 & $\begin{array}{l}\text { European } \\
\text { Gateway }\end{array}$ & $\begin{array}{l}\text { MV Passenger } \\
\text { ferry }\end{array}$ & 4263,6 & $4(2)$ & $\begin{array}{l}\text { Collided with the Bermudan registered passenger ferry MV } \\
\text { Speedlink Vanguard and capsized in heavy weather in the North } \\
\text { Sea, from Felixstowe for Rotterdam. }\end{array}$ \\
\hline 1968 & Gothic & $\begin{array}{l}\text { SS Passenger } \\
\text { cargo liner }\end{array}$ & 15902,20 & $3(4)$ & $\begin{array}{l}\text { Fire in the officers' smoking room which spread to passenger cabins, } \\
\text { South Pacific Ocean after departing New Zealand for Liverpool. }\end{array}$ \\
\hline 1966 & Anzio I & $\begin{array}{l}\text { MV Passenger } \\
\text { ship }\end{array}$ & 216,57 & $13(0)$ & $\begin{array}{l}\text { Stranded and wrecked during a gale and sleet in the North Sea off } \\
\text { Lincolnshire, on passage from Tilbury to Inverness. No survivors. }\end{array}$ \\
\hline 1961 & Dara & $\begin{array}{l}\text { MV Passenger } \\
\text { liner }\end{array}$ & 5029,13 & $25(213)$ & $\begin{array}{l}\text { Severe explosion amidships during unloading at Dubai, having } \\
\text { arrived from Bombay. Thought to have been caused by a planted } \\
\text { land mine. }\end{array}$ \\
\hline 1960 & $\begin{array}{l}\text { Capetown } \\
\text { Castle }\end{array}$ & $\begin{array}{l}\text { MV Passenger } \\
\text { liner }\end{array}$ & 27002,21 & $7(0)$ & $\begin{array}{l}\text { Explosion in the engine room in the North Atlantic, from Cape } \\
\text { Town to Las Palmas. }\end{array}$ \\
\hline 1953 & $\begin{array}{l}\text { Princess } \\
\text { Victoria }\end{array}$ & $\begin{array}{l}\text { SS Passenger } \\
\text { ferry }\end{array}$ & 2694,6 & $9(124)$ & $\begin{array}{l}\text { Capsized after the vehicles deck flooded during a severe storm, } \\
\text { when crossing the Irish Sea from Stranraer to Larne. } \\
43 \text { rescued. }\end{array}$ \\
\hline 1947 & $\begin{array}{l}\text { Reina Del } \\
\text { Pacifico }\end{array}$ & $\begin{array}{l}\text { SS Passenger } \\
\text { liner }\end{array}$ & 17702,16 & $28(0)$ & $\begin{array}{l}\text { Explosion in the engine room when undergoing sea trials in the } \\
\text { Irish Sea off Belfast. }\end{array}$ \\
\hline 1947 & $\begin{array}{l}\text { Sir Harvey } \\
\text { Adamson }\end{array}$ & $\begin{array}{l}\text { SS Passenger } \\
\text { cargo ship }\end{array}$ & 1030,32 & $64(128)$ & $\begin{array}{l}\text { Disappeared during a gale in the Bay of Bengal after departing } \\
\text { Rangoon for Tavoy. Thought to have been caused by an } \\
\text { uncleared mine. }\end{array}$ \\
\hline 1935 & Laurentic & $\begin{array}{l}\text { SS Passenger } \\
\text { liner }\end{array}$ & 18724,0 & $6(0)$ & $\begin{array}{l}\text { Collision in fog in the English Channel with the British liner SS } \\
\text { Napier Star, crew accommodation damaged, having departed } \\
\text { Plymouth for Antwerp. }\end{array}$ \\
\hline 1933 & Antung & $\begin{array}{l}\text { SS Passenger } \\
\text { cargo ship }\end{array}$ & 3508,6 & $70 *$ & $\begin{array}{l}\text { Foundered during a storm in the South China Sea, from Swatow, } \\
\text { China for Singapore. } 265 \text { rescued. }\end{array}$ \\
\hline 1928 & Vestris & $\begin{array}{l}\text { SS Passenger } \\
\text { cargo liner }\end{array}$ & 10494,0 & $43(68)$ & $\begin{array}{l}\text { Foundered following a cargo shift during a severe storm in } \\
\text { the North Atlantic, on voyage from New York to Buenos Aries. } \\
215 \text { rescued. }\end{array}$ \\
\hline 1924 & Cigale & $\begin{array}{l}\text { SS Passenger } \\
\text { cargo ship }\end{array}$ & 310,16 & $7(16)$ & $\begin{array}{l}\text { Fire and explosions in a hold that contained spirits in the Indian } \\
\text { Ocean off Mauritius. } 36 \text { saved. }\end{array}$ \\
\hline 1922 & Egypt & $\begin{array}{l}\text { SS Passenger } \\
\text { liner }\end{array}$ & 7912,24 & $71(16)$ & $\begin{array}{l}\text { Foundered after colliding with a French steamship Seine amid } \\
\text { fog in the English Channel, from Tilbury to Bombay with a cargo } \\
\text { of gold bullion. } 251 \text { survivors. }\end{array}$ \\
\hline 1921 & Rowan & $\begin{array}{l}\text { SS Passenger } \\
\text { ship }\end{array}$ & 1493,11 & $11(11)$ & $\begin{array}{l}\text { Collision in fog with an America steamship West Camak in } \\
\text { the Irish Sea, from Glasgow to Belfast. } 75 \text { rescued. }\end{array}$ \\
\hline 1920 & Bohemian & $\begin{array}{l}\text { SS Passenger } \\
\text { cargo ship }\end{array}$ & 8555,19 & $6(0)$ & $\begin{array}{l}\text { Stranded during a storm off Sandro Island, Nova Scotia, from } \\
\text { Boston, USA, for Liverpool. } 174 \text { rescued. }\end{array}$ \\
\hline 1919 & Iolaire & $\begin{array}{l}\text { Sail and steam } \\
\text { yacht }\end{array}$ & 634,17 & $20(185)$ & $\begin{array}{l}\text { Wrecked during a cyclone off the Hebrides, carrying armed } \\
\text { forces, returning from World War One. } 75 \text { saved. }\end{array}$ \\
\hline 1914 & Belgian King & $\begin{array}{l}\text { SS Passenger } \\
\text { ship }\end{array}$ & 3393, 32 & $0(22)$ & $\begin{array}{l}\text { Foundered after the cargo of cattle shifted, from Trebizonde } \\
\text { for Constantinople in the Black Sea. }\end{array}$ \\
\hline 1914 & $\begin{array}{l}\text { Empress of } \\
\text { Ireland }\end{array}$ & $\begin{array}{l}\text { RMS } \\
\text { Passenger } \\
\text { liner }\end{array}$ & 14191,8 & $172(840)$ & $\begin{array}{l}\text { Collision in dense fog with a Norwegian collier ship SS Storstad } \\
\text { in the St. Lawrence River, from Quebec for Liverpool. Foundered, } \\
238 \text { crew and } 317 \text { passengers saved. }\end{array}$ \\
\hline 1913 & Alum Chine & $\begin{array}{l}\text { SS Passenger } \\
\text { cargo }\end{array}$ & 1767,7 & $11(9)$ & $\begin{array}{l}\text { Explosions and fire on deck when loading a cargo including } \\
\text { dynamite at Baltimore. }\end{array}$ \\
\hline
\end{tabular}


Table 3 (cont.). Details of ship accidents that led to 6 or more crew or passenger fatalities in United Kingdom passenger ships: ordered chronologically

\begin{tabular}{|c|c|c|c|c|c|}
\hline Year & $\begin{array}{l}\text { Name } \\
\text { of ship }\end{array}$ & Type of ship & $\begin{array}{l}\text { Gross } \\
\text { tonnage, } \\
\text { age of ship }\end{array}$ & $\begin{array}{l}\text { Seafarers (and } \\
\text { passengers) } \\
\text { lost }\end{array}$ & Details of the maritime casualty \\
\hline 1913 & Veronese & $\begin{array}{l}\text { SS Passenger } \\
\text { liner }\end{array}$ & 7063,6 & $5(33)$ & $\begin{array}{l}\text { Stranded during a gale and fog off Porto, Portugal, from } \\
\text { Liverpool for Brazil and Argentina. } 337 \text { survived. }\end{array}$ \\
\hline 1913 & Volturno & $\begin{array}{l}\text { SS Passenger } \\
\text { liner }\end{array}$ & 3602,6 & $30(106)$ & $\begin{array}{l}\text { Fire in a hold spread through the ship during a North Atlantic } \\
\text { gale, from Rotterdam to New York with a general cargo, } \\
521 \text { rescued. Ship later scuttled. }\end{array}$ \\
\hline 1912 & Oceana & $\begin{array}{l}\text { SS Passenger } \\
\text { liner }\end{array}$ & 6610,23 & $2(7)$ & $\begin{array}{l}\text { Collision with a German barque Pisagua in the English Channel } \\
\text { off Newhaven, from Tilbury to Bombay with a cargo of gold and } \\
\text { silver ingots. } 241 \text { rescued. }\end{array}$ \\
\hline 1912 & Titanic & $\begin{array}{l}\text { RMS } \\
\text { Passenger } \\
\text { liner }\end{array}$ & 46328,0 & $696(818)$ & $\begin{array}{l}\text { Foundered after striking an iceberg in the North Atlantic, on her } \\
\text { maiden voyage from Southampton to New York. } 212 \mathrm{crew} \text { and } \\
498 \text { passengers survived. }\end{array}$ \\
\hline 1911 & Fifeshire & $\begin{array}{l}\text { SS Passenger } \\
\text { liner }\end{array}$ & 5812,12 & $14(10)$ & $\begin{array}{l}\text { Wrecked during a gale in the Gulf of Aden, on voyage from } \\
\text { Melbourne to London. }\end{array}$ \\
\hline 1910 & Loodiana & $\begin{array}{l}\text { SS Passenger } \\
\text { cargo ship }\end{array}$ & 3264,24 & $93(83)$ & $\begin{array}{l}\text { Disappeared during a cyclone in the Indian Ocean when } \\
\text { travelling from Mauritius to Colombo. }\end{array}$ \\
\hline 1910 & Abbona & $\begin{array}{l}\text { SS Passenger } \\
\text { liner }\end{array}$ & 4066,0 & $129(101)$ & $\begin{array}{l}\text { Foundered with all on board in during a severe storm in the Bay } \\
\text { of Biscay, on her maiden voyage from Glasgow to Colombo. }\end{array}$ \\
\hline 1910 & Axim & $\begin{array}{l}\text { SS Passenger } \\
\text { liner }\end{array}$ & 2804,15 & $32(4)$ & $\begin{array}{l}\text { Disappeared in a storm in the Bay of Biscay, from London for } \\
\text { the Canary Islands. All on board lost. }\end{array}$ \\
\hline 1910 & Lima & $\begin{array}{l}\text { SS Passenger } \\
\text { cargo ship }\end{array}$ & 4943,2 & $6(0)$ & $\begin{array}{l}\text { Wrecked in fog off Guamblin Island, Chile, from Liverpool on } \\
\text { voyage to Callao. }\end{array}$ \\
\hline 1909 & Ellan Vannin & $\begin{array}{l}\text { PS Passenger } \\
\text { ship }\end{array}$ & 339,48 & $21(15)$ & $\begin{array}{l}\text { Foundered with all on board during a severe storm in the River } \\
\text { Mersey estuary, having departed Ramsey, Isle of Man, for } \\
\text { Liverpool. }\end{array}$ \\
\hline 1909 & Republic & $\begin{array}{l}\text { RMS } \\
\text { Passenger } \\
\text { liner }\end{array}$ & 15378,5 & $3(3)$ & $\begin{array}{l}\text { Collision in fog with the American ship SS Florida off } \\
\text { Massachusetts, New York for Genoa. Sank next day. } \\
>1500 \text { rescued. }\end{array}$ \\
\hline 1909 & Umhlali & $\begin{array}{l}\text { SS Passenger } \\
\text { ship }\end{array}$ & 3388,3 & $0(11)$ & $\begin{array}{l}\text { Wrecked off Las Palmas, Canary Islands, in dense fog when } \\
\text { bound from London for Natal. } 109 \text { rescued. }\end{array}$ \\
\hline 1909 & Waratah & $\begin{array}{l}\text { SS Passenger } \\
\text { liner }\end{array}$ & 9339,0 & $119(92)$ & $\begin{array}{l}\text { Disappeared on her second voyage during a gale in the Cape of } \\
\text { Good Hope, bound from Australia to London. Wreckage found later. }\end{array}$ \\
\hline 1909 & Powan & $\begin{array}{l}\text { SS Passenger } \\
\text { ferry }\end{array}$ & 15,9 & $0(26)$ & $\begin{array}{l}\text { Wrecked during a storm in the South China Sea off Hong Kong, } \\
\text { on voyage from Canton for Hong Kong. }\end{array}$ \\
\hline 1908 & Sardinia & $\begin{array}{l}\text { SS Passenger } \\
\text { cargo ship }\end{array}$ & 2474,19 & $16(83)$ & $\begin{array}{l}\text { Fire in a hold containing nitrate in the Mediterranean Sea, from } \\
\text { Malta for Alexandria. } 104 \text { survivors. }\end{array}$ \\
\hline 1907 & Berlin & $\begin{array}{l}\text { SS Passenger } \\
\text { ship }\end{array}$ & 1745,12 & $48(85)$ & $\begin{array}{l}\text { Wrecked during a storm off the Hook of Holland, from Harwich. } \\
4 \text { crew and } 11 \text { passengers rescued. }\end{array}$ \\
\hline 1906 & Courier II & $\begin{array}{l}\text { SS Passenger } \\
\text { cargo ship }\end{array}$ & 152,22 & $0(10)$ & $\begin{array}{l}\text { Wrecked off Jethou, Guernsey, after departing Sark for } \\
\text { Guernsey. } 29 \text { rescued. }\end{array}$ \\
\hline 1906 & Hankow & $\begin{array}{l}\text { PS Passenger } \\
\text { ship }\end{array}$ & 3073,32 & $8(122)$ & $\begin{array}{l}\text { Gutted by a fire from a deck cargo of straw, when berthed in Hong } \\
\text { Kong harbour (estimate on pro-rata basis: declared total 130). }\end{array}$ \\
\hline 1905 & Damara & $\begin{array}{l}\text { SS Passenger } \\
\text { ship }\end{array}$ & 1779,21 & $15(0)$ & $\begin{array}{l}\text { Wrecked in a snow blizzard off Sable Island, Nova Scotia, } \\
\text { London to Halifax, Nova Scotia. } 19 \text { saved. }\end{array}$ \\
\hline 1905 & Hilda & SS Passenger & 848,22 & $27(98)$ & $\begin{array}{l}\text { Wrecked amid dense fog in the English Channel off Pierres des } \\
\text { Portes, from Southampton for St Malo. One crew member and } \\
5 \text { passengers rescued. }\end{array}$ \\
\hline 1904 & Secundra & $\begin{array}{l}\text { SS Passenger } \\
\text { cargo ship }\end{array}$ & 2160,19 & $7(0)$ & $\begin{array}{l}\text { Wrecked soon after departing Galle, Sri Lanka for New York. } \\
142 \text { rescued. }\end{array}$ \\
\hline
\end{tabular}


Table 3 (cont.). Details of ship accidents that led to 6 or more crew or passenger fatalities in United Kingdom passenger ships: ordered chronologically

\begin{tabular}{|c|c|c|c|c|c|}
\hline Year & $\begin{array}{l}\text { Name } \\
\text { of ship }\end{array}$ & Type of ship & $\begin{array}{l}\text { Gross } \\
\text { tonnage, } \\
\text { age of ship }\end{array}$ & $\begin{array}{l}\text { Seafarers (and } \\
\text { passengers) } \\
\text { lost }\end{array}$ & Details of the maritime casualty \\
\hline 1903 & Arequipa & $\begin{array}{l}\text { SS Passenger } \\
\text { cargo ship }\end{array}$ & 2953,13 & $11(52)$ & $\begin{array}{l}\text { Foundered during a severe gale when loading cargo including } \\
\text { gold at Valparaiso. } 32 \text { rescued. }\end{array}$ \\
\hline 1903 & Orion & $\begin{array}{l}\text { SS Passenger } \\
\text { cargo ship }\end{array}$ & 684,28 & $3(3)$ & $\begin{array}{l}\text { Gutted by a fire from the passengers' saloon in the Barents Sea } \\
\text { off Makkaur, Norway. }\end{array}$ \\
\hline 1903 & Upupa & $\begin{array}{l}\text { SS Passenger } \\
\text { cargo ship }\end{array}$ & 948,31 & $21(2)$ & $\begin{array}{l}\text { Disappeared during a gale in the Irish Sea off Ballycotton after } \\
\text { departing Cardiff for Cork. }\end{array}$ \\
\hline 1902 & Camorta & $\begin{array}{l}\text { Sail and steam } \\
\text { passenger }\end{array}$ & 2119,20 & $89(650)$ & $\begin{array}{l}\text { Foundered during a cyclone in the Bay of Bengal, after departing } \\
\text { Madras for Rangoon. No survivors. }\end{array}$ \\
\hline 1900 & Charkieh & $\begin{array}{l}\text { SS Passenger } \\
\text { cargo ship }\end{array}$ & 1533,34 & $21(18)$ & $\begin{array}{l}\text { Wrecked in a gale in Karystos Bay, Greece, on route for Piraeus } \\
\text { from Alexandria. } 60 \text { rescued. }\end{array}$ \\
\hline 1900 & $\begin{array}{l}\text { City of } \\
\text { Monticello }\end{array}$ & $\begin{array}{l}\text { PS Passenger } \\
\text { cargo ship }\end{array}$ & 1034,33 & $28(35)$ & $\begin{array}{l}\text { Sank during a storm in the Bay of Fundy, St. John's, } \\
\text { Newfoundland to Yarmouth, Nova Scotia. } 3 \text { saved. }\end{array}$ \\
\hline 1900 & Rossgull & $\begin{array}{l}\text { SS Passenger } \\
\text { cargo ship }\end{array}$ & 238,15 & $10(0)$ & $\begin{array}{l}\text { Wrecked during a storm off Jersey, having arrived from } \\
\text { Plymouth. } 3 \text { crew and } 8 \text { passengers rescued. }\end{array}$ \\
\hline
\end{tabular}

available information on all of those incidents where there are 6 or more fatalities. The number of survivors is noted on the table when it has been recorded. Some incidents, such as deep-sea founderings, have few if any survivors. For wrecks and collisions near to the coast the number of survivors is usually greater. The incidents that are reported include fires, where there is a threat to the integrity of the vessel but in many situations the fire is contained. Here evacuation is unlikely and numbers of fatalities are often small.

There have been few incidents involving loss of life in the most recent decades. Since 1980, the only cases refer to a collision involving a Harwich passenger ferry in the North Sea in 1982 (4 crew and passenger lost), the capsize of the Dover ferry Herald of Free Enterprise off Zeebrugge in 1987 (38 and 155 lost) and an explosion in the engine room of a Portsmouth ferry in 1998 (one crew fatality) (Fig. 2).

\section{DISCUSSION}

Like any other case series collected over a long period, there will be underlying trends that are not included in the data set, but which influence the findings. The British merchant marine and especially passenger shipping changed greatly over the $20^{\text {th }}$ century. Between 1900 and 1914 the UK fleet was dominant in world trade, including passenger transport. Between 1919 and 1939 this dominance declined, but passenger liners owned and crewed in UK provided a large proportion of services worldwide. Passenger shipping on major routes became increasingly separated from freight transport. In the years 1946-1969 there was a decline in the tonnage of passenger shipping, especially towards the end of the period when aircraft became the main means of intercontinental passenger transport. After 1970, UK shipping continued to provide ferry services and most deep sea passenger ships moved to the leisure market of cruising. Some of the reductions in incidents and fatalities is likely to be a consequence of these changes.

The greatest decline in fatalities took place between the period 1900-1914 and 1919-1939. This cannot be explained by changes in passenger transport as this came later. The reforms in passenger ship safety that followed the loss of Titanic, such as increases in the number of lifeboats and rafts may have increased the proportion of survivors, in addition to progressive improvements in ship design. Maritime radio communications became widely available and this may have contributed both by the provision of weather forecasting and by improving ship to ship communications, thus reducing collision risks and hastening the response to any serious incident on board. The introduction of radar and other electronic navigation aids from the 1940 s onwards almost certainly contributed to improvements in safety during this period.

Systematic studies of world passenger shipping risks or of those in national fleets for the twentieth century are rare. This is different from the nineteenth century, at least in the UK, where state enquiries into loss of life at sea were regularly undertaken because of public and political concern about crew and passenger deaths [11]. There are a number of publications that describe some of the more sensational ship losses but do not routinely include detailed information on fatalities [12-14]. Major disasters are, however, the subject of detailed individual reports commissioned by governments or within the maritime sector. 


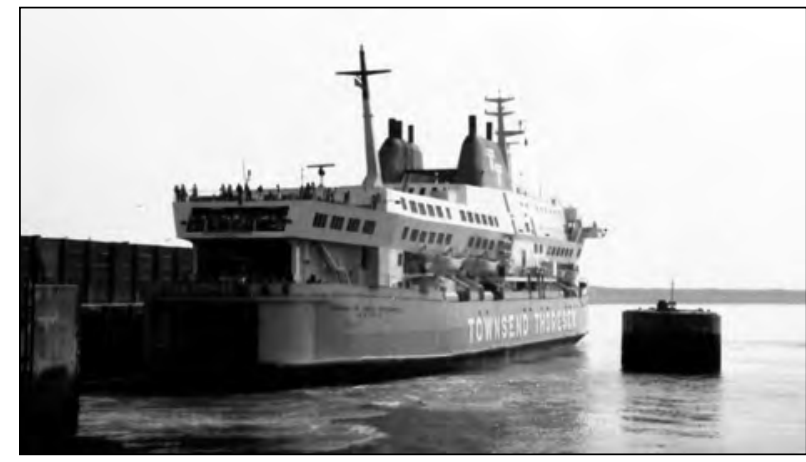

MV Herald of Free Enterprise (1987; 7951 tons)

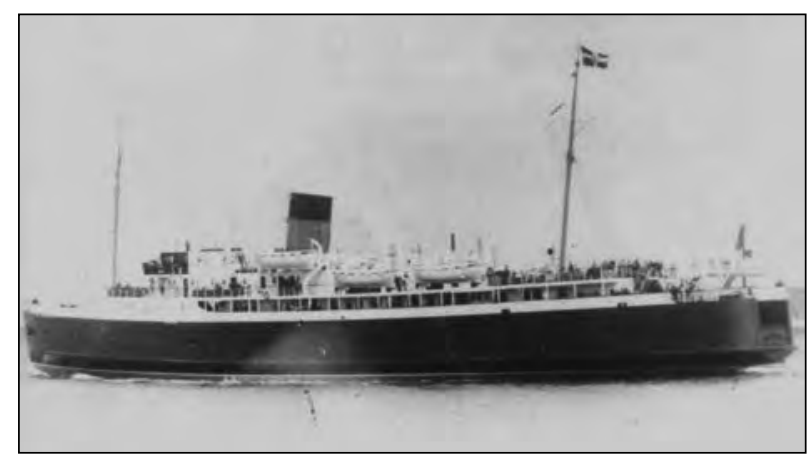

SS Princess Victoria (1953; 2694 tons)

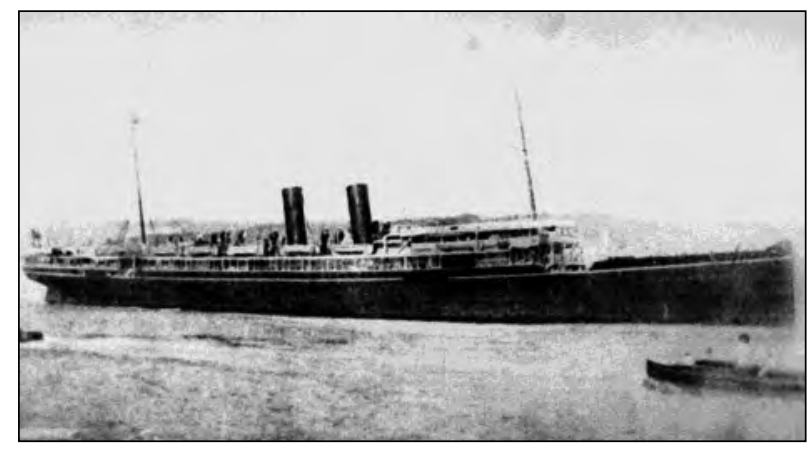

SS Egypt (1921; 7921 tons)

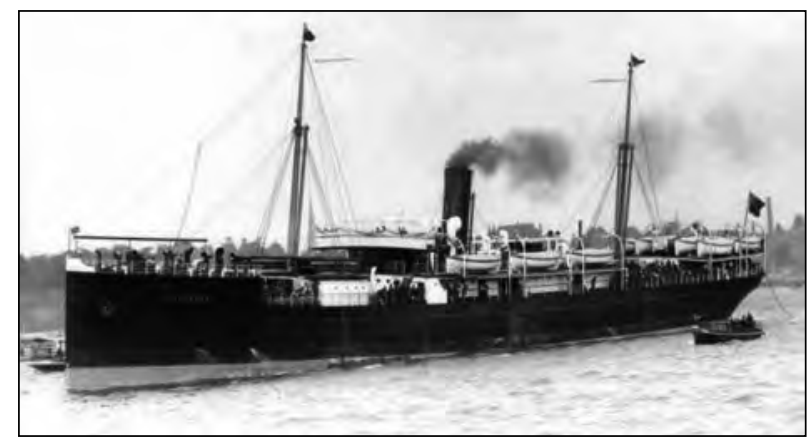

SS Volturno (1913; 3586 tons)

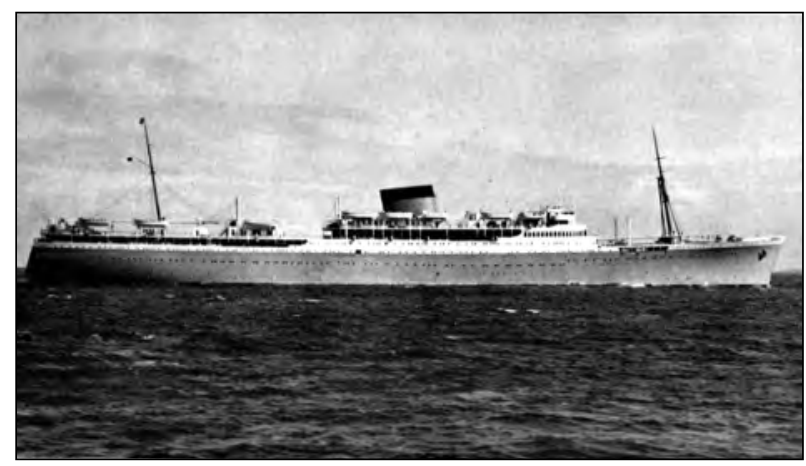

MV Capetown Castle (1960; 27,002 tons)

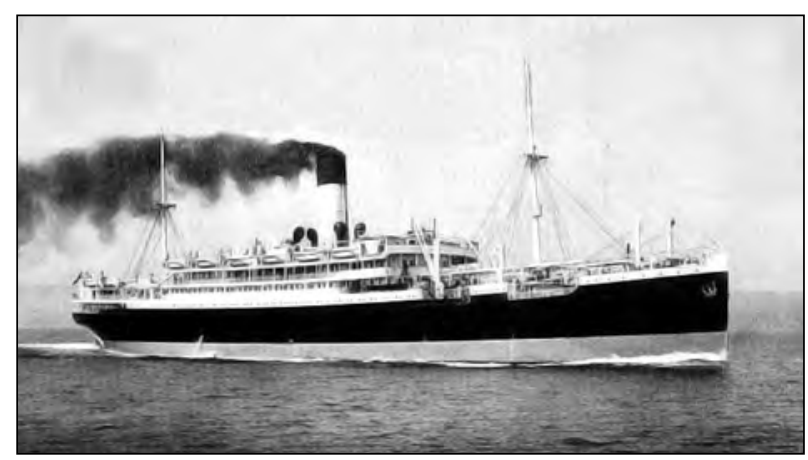

SS Vestris (1928; 10,494 tons)

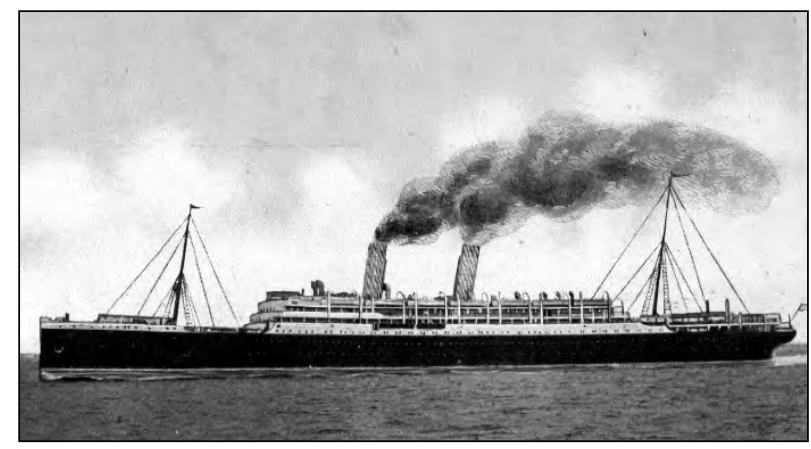

RMS Empress of Ireland (1914; 14,191 tons)

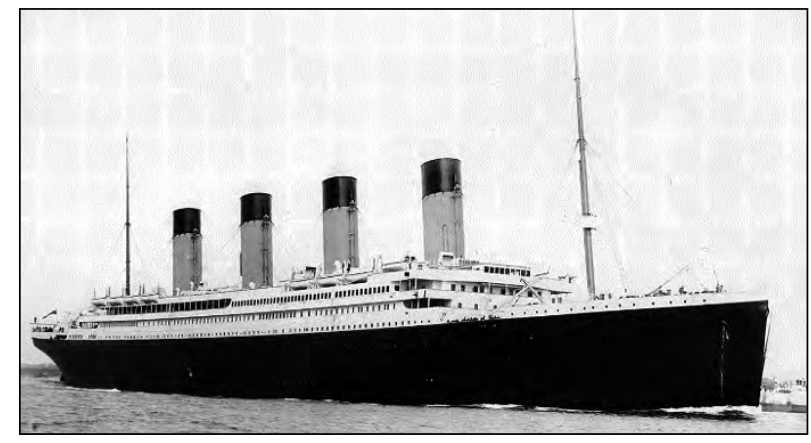

RMS Titanic (1912; 46,238 tons)

Figure 2. Photographs of United Kingdom passenger ships that were lost or had fatal ( $>$ crew or passenger fatalities) ship accidents, ordered chronologically (with year of casualty and gross tonnage in brackets) 


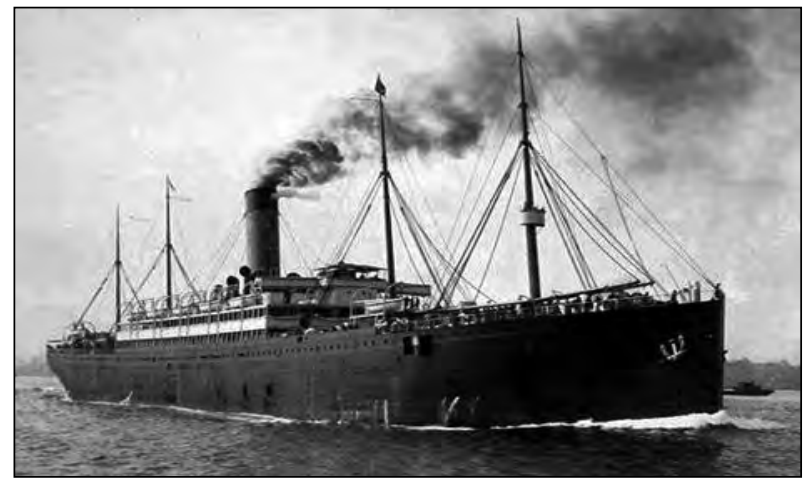

RMS Republic (1909; 15,378 tons)

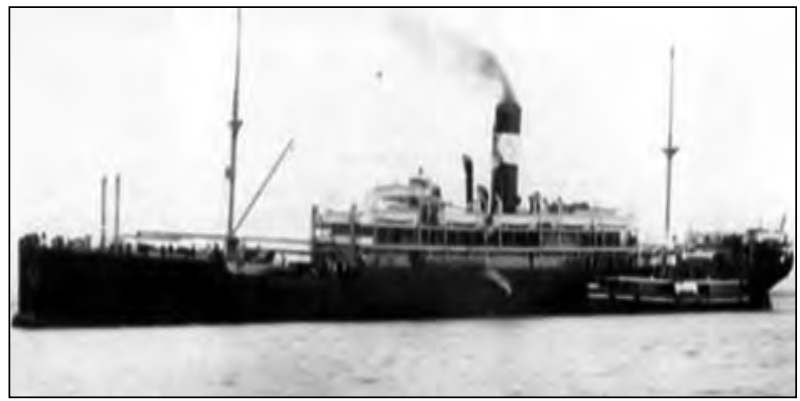

SS Waratah (1909; 9339 tons)

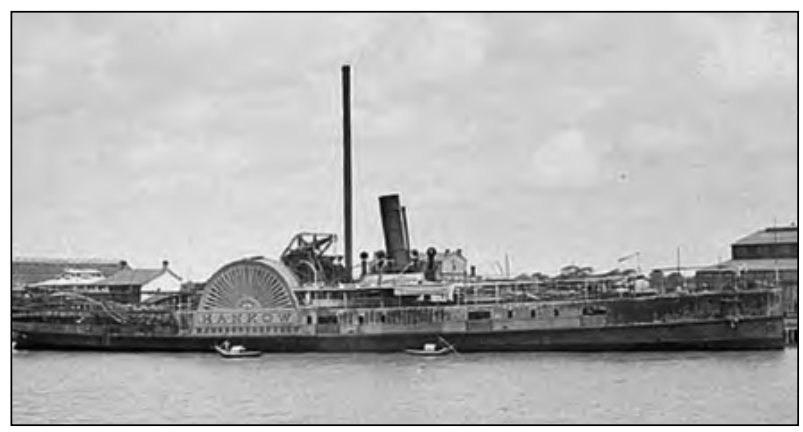

PS Hankow (1906; 3073 tons)

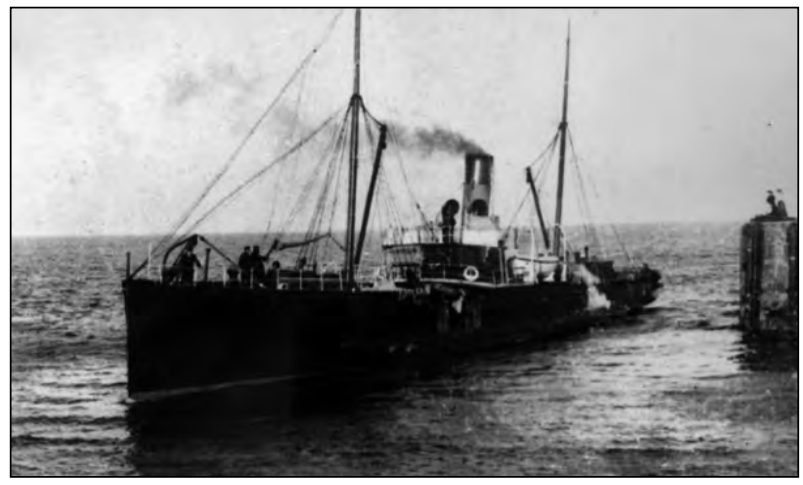

PS Ellan Vannin (1909; 339 tons)

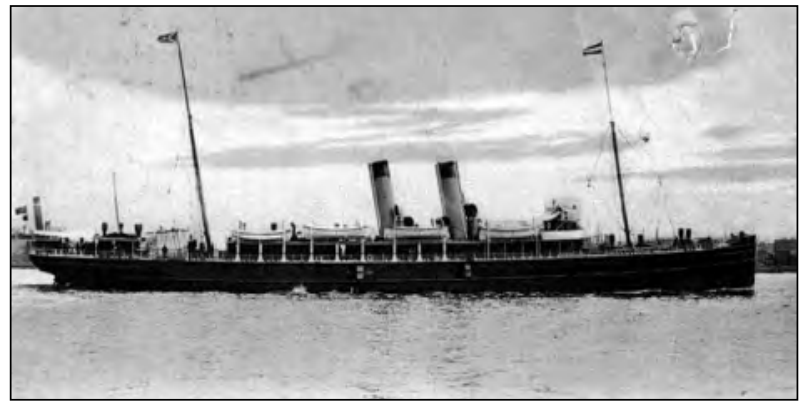

SS Berlin (1907; 1745 tons)

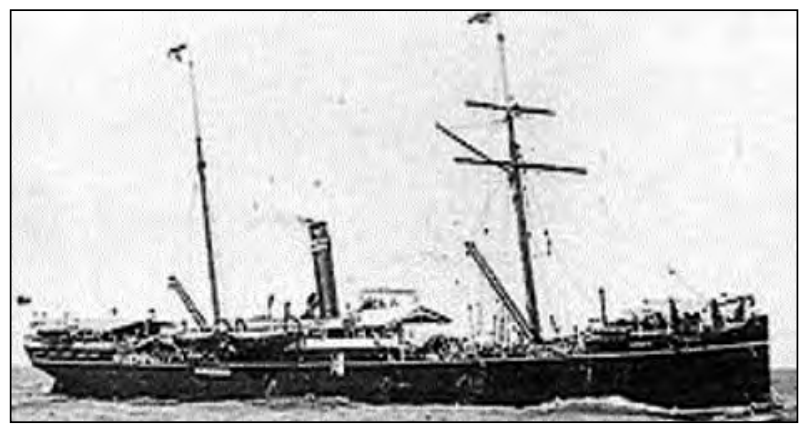

SS Camorta (1902; 2119 tons)

Figure 2 (cont.). Photographs of United Kingdom passenger ships that were lost or had fatal (> 6 crew or passenger fatalities) ship accidents, ordered chronologically (with year of casualty and gross tonnage in brackets)

Watson [12] provides some summary information on the international passenger ship losses that he describes for the period 1900-1986, his is a selective list of the largest vessels lost, not all of which result in fatalities. Notable findings are the high proportion of losses that are to UK ships, 68 out of his total of 199, with the next countries being France at 23 and Italy at 17 . This reflects the relative size of the three countries' passenger fleets in this period [15]. The trend information he presents broadly aligns with our study, but uses different time periods.

One of the notable features of our casualty data is the predominance of a few major incidents as the major causes of loss of life during each of the periods studied. The effect of this on the frequency of fatalities can be seen in Figure 1. Such major incidents have featured prominently in the public perceptions of risk at sea and have continued to do so following more recent incidents affecting ships of other flags such as the foundering of the Estonian Ro-Ro ferry Estonia during a crossing of the Baltic Sea in 1994, which led to over 800 deaths. The grounding of the cruise ship Costa Concordia in 2012, with 32 deaths led to even greater public interest as it was visible to all, had overtones of navigational failure and affected the sort of cruise liner that many people had holidayed on.

While there have been no major disasters involving UK passenger ships over the last 30 years, other major casu- 
alties with heavy loss of life have continued in the world passenger fleet $[4,5,7]$. These also include the Greek ferry Express Samina which struck a rock off Paros Island in the Aegean Sea in 2000 with 81 deaths and the Panamanian RoRo ferry Al-Salam Boccaccio 98 which foundered in the Red Sea with more than 1000 lives lost in 2006. Additionally, since 2000, casualties involving 4 Philippine (Maria Carmela, Princess of the Stars, Superferry 14 and St. Thomas Aquinas) and 4 Indonesian passenger ships (Digul, Dumai Express 10, Senopati Nusantara and Tristar 1) alone have led to more than 1700 fatalities, while another 1863 crew and passengers were lost through the foundering of the Senegal ferry Le Joola during storms off Dakar in 2002.

To cover the long time period studied we have used the standard classification of maritime disasters that has long been used by Lloyds Register [4]. This attempts to define a single, usually proximate, cause for an incident. In recent years there has been a growing literature that has looked in more detail at risk assessment and risk management of vessels, including those carrying passengers [16-18]. Such analysis has the potential to provide more detailed insights about causation, in particular the contributions of human factors [19, 20], and technical aspects of ship design [21]. Risk management and risk mitigation are usually analysed separately, with a particular focus on passenger evacuation procedures as a major contributor to survival after an incident [22]. A number of recent publications use historic data as the basis for predictive models and these can be a valuable source of more detailed information on incidents and on the realities of risk management and mitigation in passenger shipping [23-25].

Maritime incidents are only one contributor to death and morbidity in passenger shipping [25, 27]. Both passengers and crew members can sustain injuries and, in the case of crew these are frequently work-related [28-30]. Both groups can develop illness while at sea. Such risks can be reduced by good safety practices, fitness criteria for crewmembers and sometimes for passengers and the provision of facilities for medical care on board. There is conflicting evidence about changes in the relative importance of major incidents, occupational and other accidents and illness to deaths and morbidity at sea [31].

Passenger travel by sea has become far safer than it was in 1900. It is not, however, possible to analyse the causation of incidents in the same detail for most historic events as can be done in the immediate aftermath of major incidents, although this has been attempted for some of the best documented major incidents, for instance by comparing the loss of RMS Titanic with that of Costa Concordia [32, 33].

Because of their drama, visibility and issues such as liability and potential for multiple fatalities among passengers, it is the major incidents that have commanded most attention and concern. This has not abated, despite the long term reductions in risk. As the numbers of passengers and crewmembers on a single vessel increases so does the worst case scenario of total loss with few or no survivors. The very low probability of such an incident does little to downgrade the levels of concern and even sensationalism.

The expectations of travellers have more than kept pace with improvements in safety, as well as being influenced by comparisons of the safety cultures and their effects on risk in different modes of passenger transport, such as rail, road and air. The change from shipping as a necessity, because it was the sole means of intercontinental travel, to a luxury as a capital intensive part of the leisure sector has also influenced attitudes and led to new approaches to risk assessment and mitigation.

The relative level of concern about passenger risk compared with that of crewmembers has been one of the drivers for higher standards in passenger shipping than in cargo transport [34-36]. It does have to be remembered that passenger and crew fatalities correlate with each other [37]. Some $30 \%$ of fatalities throughout the period studied have been in crew members and, given their greater exposure to risk of personal accidents as well as accidents to their ship throughout the whole of their careers, rather than just when on an occasional voyage, their lifetime risk remains far higher than the passengers they transport, even if it has a lower public and political profile.

\section{ACKNOWLEDGEMENTS}

The authors thank Cathy Pennock, Audrey Hodges and the Marine Accident Investigation Branch for helpful advice and provision of marine accident investigation files, Vaughan Pomeroy and John Crilley for help with Lloyd's Register casualty returns and data, and the Registry of Shipping and Seamen for providing access to death enquiry files and death registers.

\section{REFERENCES}

1. Roberts SE, Carter T. Mortality from accidents, disease, suicide and homicide in the British fishing industry from 1900 to 2010. Int Marit Health. 2015; 66(4): 211-219, doi: 10.5603/IMH.2015.0042, indexed in Pubmed: 26726892.

2. Roberts SE, Carter T. Causes and circumstances of maritime casualties and crew fatalities in British merchant shipping since 1925. Int Marit Health. 2018; 69(2): 99-109, doi: 10.5603/ IMH.2018.0015, indexed in Pubmed: 29939386.

3. Official marine accident investigation reports (conducted variously by the Marine Accident Investigation Branch, the Board of Trade, Ministry of Transport, Department of Trade and Industry, Department of Industry, Department of Trade/Department of Transport.

4. Lloyd's Register of Shipping. Casualty returns, 1900-2010. London: Lloyd's Register of Shipping. 1901-2011.

5. Lloyd's Register of Shipping. Casualty data, 1980-2005 (casualty data from Lloyd's). 
6. Hooke N. Maritime Casualties 1963-1996. Lloyd's Maritime Information Services, London 1997.

7. Wrecksite EU. www.wrecksite.eu (1st March 2018).

8. British Newspapers Archive. www.britishnewspaperarchive. co.uk (1st March 2018).

9. Welsh Newspapers Online. https://newspapers.library.wales/ (1st March 2018)

10. Ships Nostalgia. www.shipsnostalgia.com/ (1st March 2018).

11. Royal Commission on Loss of Life at Sea. First report of the Royal Commission on Loss of Life at Sea with minutes of evidence. London: Eyre and Spottiswoode. 1885.

12. Watson MH. Disasters at Sea. Patrick Stephens, Wellingborough 1987.

13. List of Maritime Disasters (Wikipedia). https://en.wikipedia.org (1st March 2018).

14. The world's worst cruise ship disasters. https://www.ship-technology.com/features/featurethe-worlds-deadliest-cruise-shipdisasters-4181089/ (20 February 2014)

15. Watson MH. Disasters at Sea. Patrick Stephens, Wellingborough 1987: 185-186.

16. Kristiansen S. Maritime transportation: safety management and risk analysis. London, Routledge. 2013.

17. Fowler T, Sorgard E. Modeling ship transportation risk. Risk Analysis. 2002; 20(2): 225-244, doi: 10.1111/0272-4332.202022.

18. Vanem E, Skjong R. Collision and Grounding of Passenger Ships - risk assessment and emergency evacuations. DNV Research.

19. Chauvin C, Lardjane S, Morel G, et al. Human and organisational factors in maritime accidents: analysis of collisions at sea using the HFACS. Accid Anal Prev. 2013; 59: 26-37, doi: 10.1016/j. aap.2013.05.006, indexed in Pubmed: 23764875.

20. Hetherington C, Flin R, Mearns K. Safety in shipping: the human element. J Safety Res. 2006; 37(4): 401-411, doi: 10.1016/j. jsr.2006.04.007, indexed in Pubmed: 17046789.

21. Vassalos D. Damage stability and survivability - 'nailing' passenger ship safety problems. Ships and Offshore Structures. 2013; 9(3): 237-256, doi:10.1080/17445302.2013.780397.

22. Lee $\mathrm{D}$, Kim H, Park JH, et al. The current status and future issues in human evacuation from ships. Safety Science. 2003; 41(10): 861-876, doi:10.1016/s0925-7535(02)00046-2.

23. Eleftheria E, Apostolos P, Markos V. Statistical analysis of ship accidents and review of safety level. Safety Science. 2016; 85: 282-292.
24. Soares C, Teixeira AP. Risk assessment in maritime transportation. Reliability Engineering \& System Safety. 2001; 74(3): 299-309, doi:10.1016/s0951-8320(01)00104-1.

25. Łozowicka D, Kaup M. Analysis of the cause and effect of passenger ship accidents in the Baltic Sea. Scien J Marit University of Szczecin. 2015; 44: 68-73.

26. Roberts SE, Marlow PB. Traumatic work related mortality among seafarers employed in British merchant shipping, 1976-2002. Occup Environ Med. 2005; 62(3): 172-180, doi: 10.1136/ oem.2003.012377, indexed in Pubmed: 15723882.

27. Roberts SE, Nielsen D, Kotłowski A, et al. Fatal accidents and injuries among merchant seafarers worldwide. Occupational Medicine. 2014; 64(4): 259-266, doi: 10.1093/occmed/kqu017.

28. Dahl E. Passenger accidents and injuries reported during 3 years on a cruise ship. Int Marit Health. 2010; 61(1): 1-8, indexed in Pubmed: 20496320.

29. Hansen HL, Nielsen D, Frydenberg M. Occupational accidents aboard merchant ships. Occup Environ Med. 2002; 59(2): 85-91, indexed in Pubmed:11850550.

30. Roberts SE, Hansen HL. An analysis of the causes of mortality among seafarers in the British merchant fleet (1986-1995) and recommendations for their reduction. Occup Med (Lond). 2002; 52(4): 195-202, indexed in Pubmed: 12091585.

31. Størkersen K, Antonsen S, Kongsvik T. One size fits all? Safety management regulation of ship accidents and personal injuries. J Risk Res. 2017; 20(9): 1154-1172, doi: 10.1080/13669877.2016.1147487.

32. Hollinagel E, Baldau M. From Titanic to Costa Concordia - a century of lessons not learned. WMU Journal of Maritime Affairs. 2012; 11: 151-167.

33. Anon. Safety and Shipping 1912-2012: from Titanic to Costa Concordia. Allianz Insurance, 2012.https://www.agcs.allianz.com/ assets/PDFs/Reports/AGCS_Safety_and_Shipping_Executive_Summary.pdf (1st March 2018).

34. Brown DK. Maritime Disasters and the Law. In: Inkster I, Editor. History of Technology. Continuum , London 2005: 89-96.

35. Lois $\mathrm{P}$, Wang $\mathrm{J}$, Wall $\mathrm{A}$, et al. Formal safety assessment of cruise ships. Tourism Management. 2004; 25(1): 93-109, doi: 10.1016/ s0261-5177(03)00066-9.

36. Ventikos N. Exploring Fire Incidents/Accidents Onboard Cruise and Passenger Ships. SPOUDAI J Econ Busin. 2013; 63: 146-157.

37. Yip TL, Jin Di, Talley WK. Determinants of injuries in passenger vessel accidents. Accid Anal Prev. 2015; 82: 112-117, doi: 10.1016/j. aap.2015.05.025, indexed in Pubmed: 26070017. 